\title{
VALORIZATION OF ENTREPRENEURSHIP THROUGH THE EXERCISE COMPANY, THE REAL PREMISE OF SUSTAINABLE RURAL DEVELOPMENT
}

\author{
Geanina-Valentina LUPU ${ }^{a^{*}}$, Costel CEOCEA ${ }^{b}$, Alina Bianca POP ${ }^{c}$, Aurel Mihail ȚîȚU \\ ${ }^{a}$ University of Agriculture and Veterinary Medicine, Bucharest, Romania \\ ${ }^{b}$ Vasile Alecsandri University of Bacău, Romania \\ ${ }^{c}$ Technical University of Cluj-Napoca, Northern University Centre of Baia Mare, Romania \\ ${ }^{d}$ Lucian Blaga University of Sibiu, Academy of Romanian Scientists, Romania
}

\begin{abstract}
Entrepreneurship is a modern economic concept that positively influences the economy as a whole. Today there are more and more businesses that require skilled labor and sustained economic growth. The European Union also contributes to this idea through a series of social objectives such as eliminating urban-rural disparities, stimulating entrepreneurship, rural development. Entrepreneurship is valued in the compulsory curriculum for the technological chain of the high school through the training company. This paper starts from the idea that students in rural areas are able to perform with the help of the exercise company, to develop their entrepreneurial knowledge. This article is based on a method of quantitative and qualitative research of national and international literature. The main tools used were the experiment and the survey using the questionnaire. The examination and interpretation of the obtained results highlighted conclusions regarding the impact of the exercise company for the capitalization of entrepreneurship among high school students in rural areas. The skilled and educated workforce is the basis for generational renewal, reducing the rate of depopulation, especially in rural areas, and building a solid foundation for increasing the quality of life leading to sustainable rural development.
\end{abstract}

KEYWORDS: economic growth, entrepreneurship; exercise company; performance; skilled labor force.

\section{DOI: 10.24818/IMC/2021/03.05}

\section{INTRODUCTION}

This paper aims to study the impact that the concept of the exercise company has on students in high school classes, technological chain, service profile, on the assimilation and applicability of entrepreneurial knowledge. The two research tools are presented, the experiment and the questionnaire, which allowed the conclusions to be drawn. In the paper, several aspects of the literature on entrepreneurship are highlighted. It is considered a priority for education and training at European level, with particular attention being paid to its inclusion in strategies and policies implemented at national level. The paper briefly describes the concept of the exercise company and the introduction of this method as mandatory in the high school curriculum, service profile.

Taking into account the fact that the present study was conducted in rural areas, a brief analysis of the rural environment in terms of demographics, economy, employment, income.

The research itself highlights the participations in the profile competitions and the results obtained. The answers to the questionnaire are presented and interpretations are made.

\footnotetext{
* Corresponding author. E-mail address: geaninavlupu@gmail.com
} 


\section{MATERIAL AND METHOD}

Over the paper, the domestic and international specialized literature was studied, the data regarding the researched notions were analyzed quantitatively and qualitatively. The study is based on an experiment conducted during two school years, 2018-2019 and 2019-2020 regarding the exercise company "Royal Guard" SRL which operates within the Technological High School "Tudor Vladimirescu" in Tudor Vladimirescu commune, Galati County.

Over the two school years, the evolution of the exercise company and the capitalization of entrepreneurial knowledge were followed by participating in specialized competitions, such as the fairs of the exercise companies. At the end of the period, a questionnaire was applied to high school students, through which an opinion poll was conducted on the students' opinion regarding the contribution of the firm method of exercise for the development of entrepreneurial spirit.

\section{RESULTS AND DISCUSSIONS}

\subsection{Entrepreneurship}

From the first use of the notion of entrepreneurship by Cantillon (2001), to the proposal of numerous theories on entrepreneurship, the literature recognizes its importance and special impact at the micro and macroeconomic level. J. A. Schumpeter (1949) considers entrepreneurship to be the main driver of the economic system.

The structural transformation of the economy as a whole, based on agriculture, industries and services developed in accordance with the most advanced technologies, leads to economic growth. The specialized literature approaches entrepreneurship from several points of view, highlighting certain dominant characteristics in its definition, such as: identifying opportunities and building a business (Timmons, 1989, pp.1); discovering, creating and exploiting new business opportunities (Wennerkers \& Thurik, 1999, pp.47); the development of creative thinking combined with the management of resources for adaptation to the environment in order to achieve the expected results (Smart \& Conant, 1994, pp. 1); revitalizing mature companies by discovering new opportunities (Eroğlu \& Piçac, 2011, pp.146).

The following first factors must compete for the success of entrepreneurship: innovation, legislation, institutional framework, education, entrepreneurial culture and taxation.

According to Druker (1993), innovation is the means by which the proposed service or product is improved by an appropriate economic value.

The sources of innovation, in fact its symptoms, are found, in part, within the organization, these being: the unforeseen, the incongruity, the need for the process, the inherent changes. Other sources of innovation are found outside the organizations, identifying in this sense: changes in mentality, disposition and understanding, demography and new knowledge.

As a result of the study conducted by Harvard Business School, the personality traits that characterize an entrepreneur can be: openness to new experiences, conscientiousness, extraversion, neuroticism and altruism (Kerr, Kerr \& Xu, 2017).

The entrepreneur is the one who, overcoming uncertainties and obstacles, assumes risks, responsibilities, is a factor of change and innovation. All these qualities are sustained by selfcontrol, the use of criticism in a constructive sense, organization, perseverance and profit. As a result of the study conducted by Global Entrepreneurship Monitor in 2018-2019, internationally, Figure 1 shows the revenues obtained divided into three categories (small, medium and large) related to entrepreneurial businesses in the early stages, depending on the field of activity. A visible trend is the increase of revenues in the field of information communication technology. 


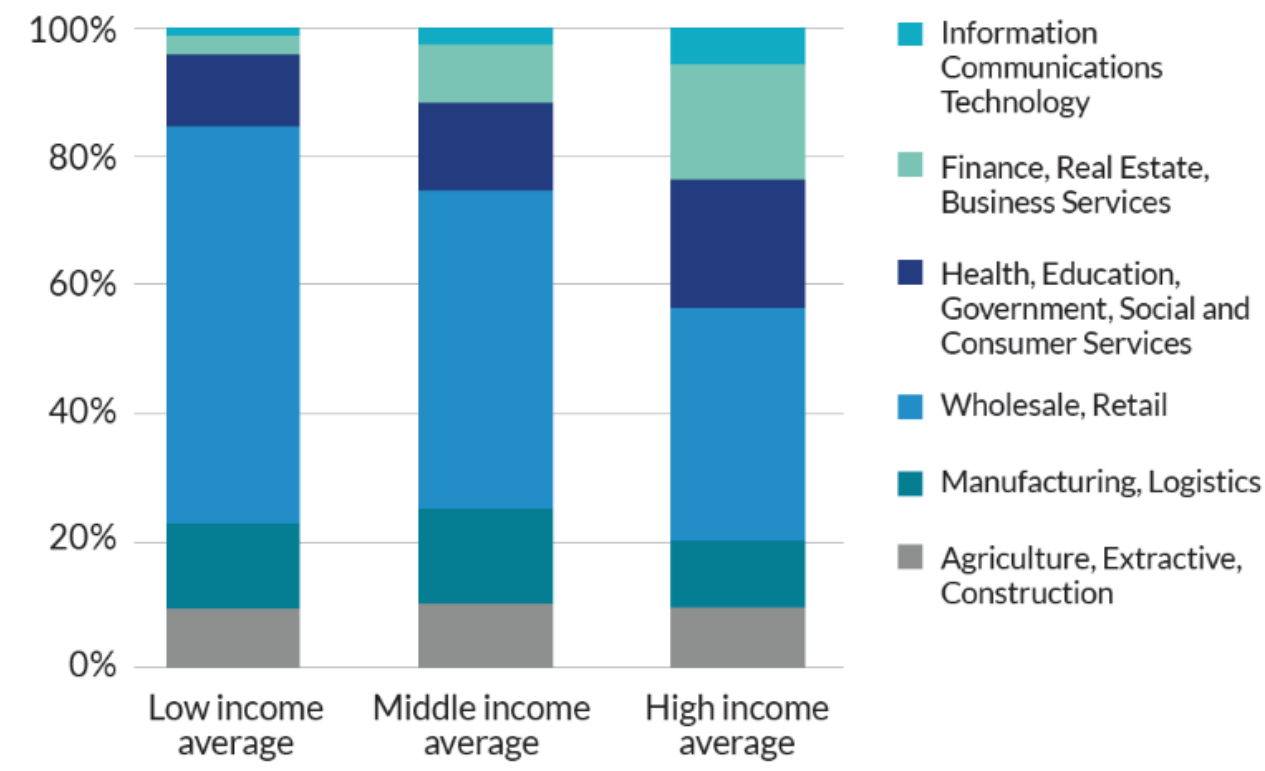

Figure 1. The level of income depending on the field of activity for start-up businesses Source: Global Entrepreneurship Monitor, (2019, pp. 29)

Taking the risk remains the main factor for the successful realization and development of your own business. Effective risk assessment involves assessing the probability and impact of a risk-based event, determining the risk profile and treatment priorities (Țîțu, Pop \& Ceocea, 2019). Regarding the reaction of Romanian managers to risks, $70 \%$ of them appreciated that the person in charge of risk management is the general manager. But, approximately $16 \%$ of them, consider that the financial and economic manager must assume responsibilities in this regard (Ceocea, Bibire $\&$ Ghenadi, 2014). The statistical indicators that are taken into account for the construction of the managerial decision are: own responsibility, responsibility to lead, responsibility for each employee. To a large extent, the obligation of risk management belongs to the management team, and less to the individual employees of the company (Ceocea, 2014, pp. 26).

\subsection{European concerns for capitalizing on entrepreneurship education}

Regarding the way in which managers have accumulated notions of risk management, in a proportion of $70 \%$ stated that they acquired them practically, working within the company. Many of them claim that they have acquired such knowledge about risk through training courses, seminars and conferences on these topics, studying other sources of information, especially through the internet. Hence the need to learn in an organized way about what management and entrepreneurship mean.

A key goal of the European Union is to encourage a mentality towards entrepreneurship among citizens, businesses and all bodies in the Member States. The constantly moving, adapting and digitizing economy depends on the skilled workforce that can adapt through knowledge, attitudes and skills to the requirements of the labor market. Among the main objectives of the Strategic Framework for Vocational Education and Training (ET 2020) is to stimulate creativity, innovation and entrepreneurship at all levels of education and training. One of the eight key competences underpinning the European Union's policy on lifelong learning is that of entrepreneurship education. Member States need to encourage entrepreneurial skills through new and creative ways of teaching and from secondary to higher education they need to emphasize the possibility of setting up a business as a future career (European Commission, 2012).

Regarding the national strategy adopted on entrepreneurial skills, the approaches of the EU Member States were different: some states have strategies that depend on education and training (Greece, 
Turkey, Latvia) others those of youth (Serbia, Slovenia and Slovakia). Some approach entrepreneurship in relation to lifelong learning (Austria, Poland, Bulgaria and Hungary). Other states link these competencies to general strategies. Some countries have developed a strategy outside of education and training, and others link them to the innovation sector (Czech Republic, France, Denmark) and the economic development sector (Lithuania, Spain and Romania) (European Commission, 2016).

In Romania, the strategy on entrepreneurship education was closely linked to the economic development sector in the "Strategy for the development of the small and medium enterprises sector" as well as in the development of the business environment in Romania Horizon 2020. It supports actions to support business firms, teacher training and web platforms to increase entrepreneurship education.

Initial education and training have an immediate consequence on the employment of young people in the labor market. Romania was among the first countries to try to modernize the vocational and technical education system (TVET). With the help of European funds, initiatives have been developed to change the curriculum.

Pre-university education is divided into levels, forms of education, courses and profiles. Vocational and technical education consists of technological high school education, vocational education, dual education and post-secondary education. In technological high school education, vocational training standards and curriculum have been modified by implementing the project "Revised Curriculum in Vocational and Technical Education (CRIPT)", ID 58832, funded by the European Social Fund, Sectoral Operational Program Human Resources Development 2007-2013, Priority Axis 1 "Vocational education and training in support of economic growth and development of the knowledge-based society", major area of intervention 1.1 "Access to quality initial vocational education and training" as shown in Annex 2 to OMEN no. 3501 / 29.03.2018.

\subsection{Approaches to the exercise company concept}

According to the curriculum for the 11th and 12th grade, the field of trade, the professional qualification of technician in trade activities, annex no. 2 to OMEN no.3501 / 29.03.2018, the exercise company is a modern, interactive learning concept for learning to develop entrepreneurship, an innovative concept of integration and interdisciplinary application of knowledge, skills and attitudes, an approach that provides conditions for testing and practical deepening of the learning outcomes acquired by students in vocational training.

The methodological approach of the exercise company emphasizes learning in four key areas that apply the "learning by doing" method: ownership: students take responsibility for their own learning; experiential: student learning is authentic and realistic; cooperative: learners learn with and from others and understand the dynamics of working as part of a team; reflective: learners experience the consequences of their decisions and apply this learning to future challenges. Internationally, the name of the exercise company may vary from country to country such as (Practice Firm, Training Firm, Virtual Enterprise), but also as a translation (Entreprise d'entraînement, Übungsfirma, Empresa Simulada).

In Romania, this method was achieved between 2001-2004 with the help of the ECONET project within the Stability Pact for South-Eastern Europe through the National Center for the Development of Vocational and Technical Education (CNDÎPT), the Ministry of Education and Kultur Kontakt Austria. Due to the positive impact on students and teachers, at the end of the project, it was decided to introduce the method as compulsory in vocational and technical education units, service profile through OMEC no. 3172/2006 starting with the school year 2006-2007, and since 2001 the ROCT platform has been developed, specific to the exercise companies (Europen-Pen International, 2020). As figure 2 demonstrates, the exercise companies have an exponential growth from 2001 to 2019. If the beginning was timid with only 34 active companies, the success of this concept is demonstrated by the 1459 active companies in the 2018-2019 school year. 


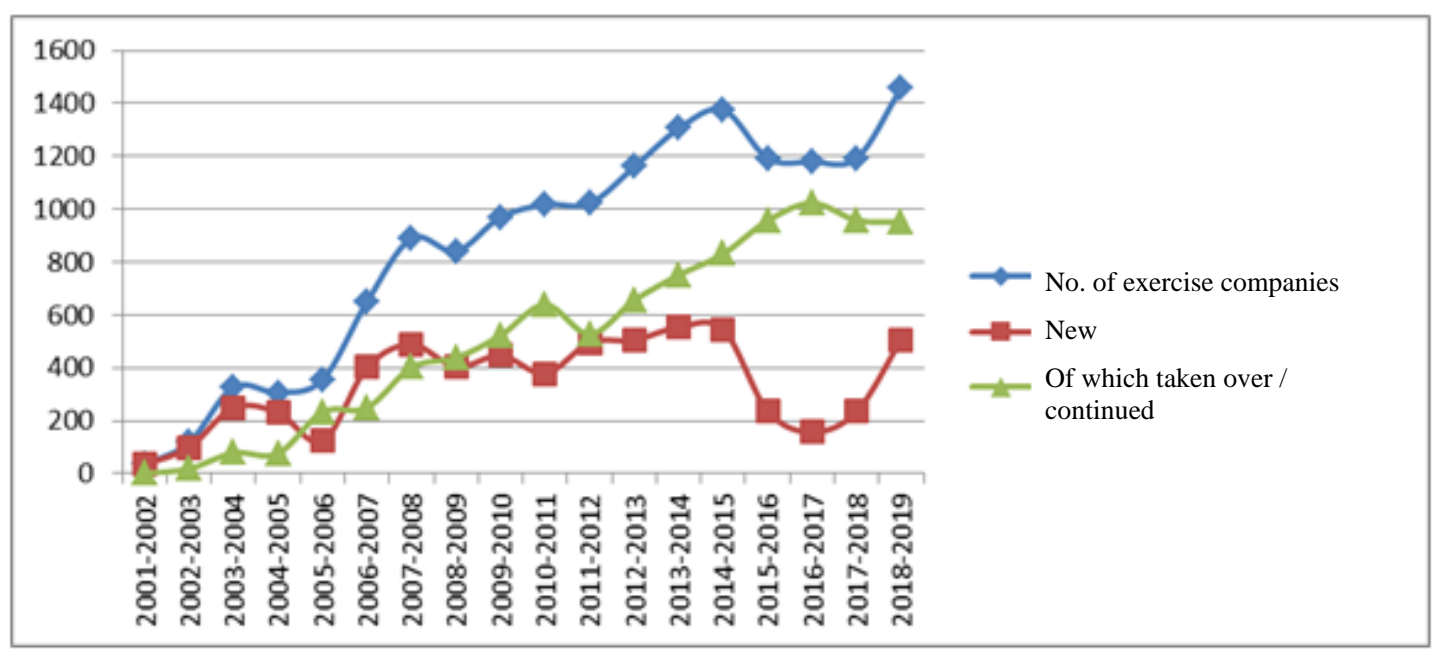

Figure 2. Dynamics of exercise companies in the period $2001-2019$

Source: data processed by the author according to ROCT http://www.roct.ro/situatie-statistica/

An exercise company is a simulated one, in which economic processes similar to those of real companies are carried out. It is a didactic concept, with an attractive educational purpose for students.

Characteristics characteristic of exercise companies:

- properly furnished school office, with furniture, computers, printers, internet access for carrying out economic and commercial operations according to the real requirements of the business environment;

- the organizational structure made on departments such as human resources, financial-accounting, marketing, commercial, secretarial;

- money and goods are virtual;

- national and international law is complied with;

- facilitates the accumulation of theoretical knowledge and the formation of skills and attitudes in accordance with the positions held within the exercise company under the coordination of the teacher;

- different professionals from multiple sectors of the national economy may be involved;

- eliminates risk through the virtuality of money and goods, which means that the wrong decisions made within the company do not really affect students, but provide learning situations.

As the statistics show, the number of companies has grown exponentially. In this sense, an important role is played by teachers who teach the specific disciplines of this concept to find the best ways, through a series of active-participatory methods to motivate students to apply this concept first virtually, and then concretely, in the real economic world. . Even if the activeparticipatory methods prevail within the exercise company, they do not exclude, but include and support the need for traditional, consecrated methods, used by teachers. An important aspect worth considering is that the methods do not exist in their pure state, but, depending on the aspects followed and the way of application, they can be traditional, algorithmic, to stimulate creativity, personality, or they can be active. If we take the example of the conversation, which is a classic method, if it is done by the teacher, and if the students are involved through questions, the activity is done with their participation, the method becoming active. We mention that the methods are not in themselves good or bad, but by combining them correctly the learning outcomes can be achieved. 


\subsection{Developing the entrepreneurial spirit through the exercise company within the rural high schools. Considerations on rural environment and rural education}

Because the study was conducted in a high school in rural areas, we consider it important to form an overview, the presentation of aspects related to this environment, as well as the education conducted in this framework.

If we talk about the rural environment, we are undoubtedly talking about agriculture, the labor force involved in this sector and family farms. According to Eurostat data, Romania has approximately 3.4 million farms in 2018, ranking first in the European Union. 96\% of these holdings are considered family, which means that at least half are managed by the family, and about half of the agricultural work is done only by family workers. It follows that $22.8 \%$ of the total workforce was employed in agriculture in 2018 (European Commission, 2019).

After 30 years of negative natural increase at national level and in the context of significant emigration flows, with a resident population of 19.4 million people, in 2019, the decrease of the resident population is evident especially in rural areas. The situation of employment and unemployment in rural areas is worrying, as shown in Figure 3. Over time, there has been a sharp decline in employment opportunities in rural areas. While in cities, the number of unemployed has decreased steadily, in villages, unemployment has remained high in recent years.

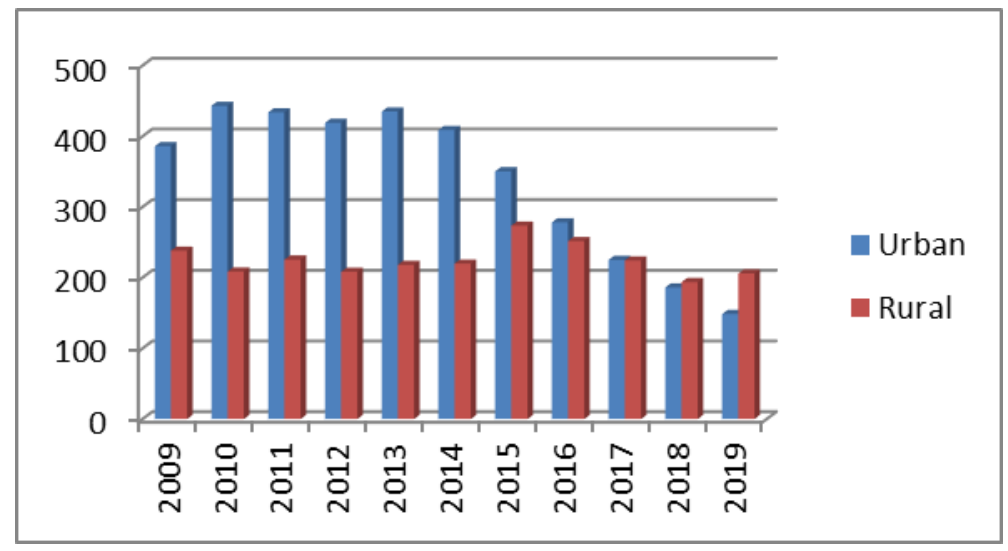

Figure 3. Unemployed by means of residence according to the ILO Source: INSSE - Tempo Online

This is closely related to the employment rate of the active population, which is increasing in cities but steadily declining in rural areas. A particular situation is experienced by people who practice subsistence agriculture and who are classified as unemployed. According to the data of the National Institute of Statistics, for 2018, the poverty line was 902 lei per person, and one person from agricultural holdings earned an average total monthly income of 848.9 lei. Subsistence farming, low incomes, lack of infrastructure, underline a significant difference between urban and rural areas in terms of respecting the chances of quality of life.

The labor force in agriculture is aging, this fact also stemming from the fact that $41 \%$ of Romanian farmers are over 65 years old, and very few of the managers of agricultural exploitations are under 35 years old. The European Union raises the issue of attracting the younger generation to agriculture, mainly from the perspective of an aging population. In Romania, the problem is marked by at least three difficulties: the aging population, the overwhelming migration of young people and the difficulty of attracting young people with professional training to the field of agriculture. The need to promote intergenerational transfer in agriculture is already under discussion in the European Commission and is an important directive of the new Common Agricultural Policy after 2020.

At present, there is no educational strategy to address the need for professionalization for entrepreneurship in agriculture. The vast majority of educational policies focus only on the employability of young graduates. There is an acute need to increase the attention paid to cross- 
curricular skills, especially entrepreneurial ones in the school curriculum in TVET in general, but especially in agriculture (Toderiță \& Tom, 2019).

Regarding the situation of education for the school year 2019-2020, it was presented according to figure 4. If we consider the southeastern region where the high school where the research was conducted, we can see that for the high school level, it is on the 3 of the regions of the country in favor of this type of education.

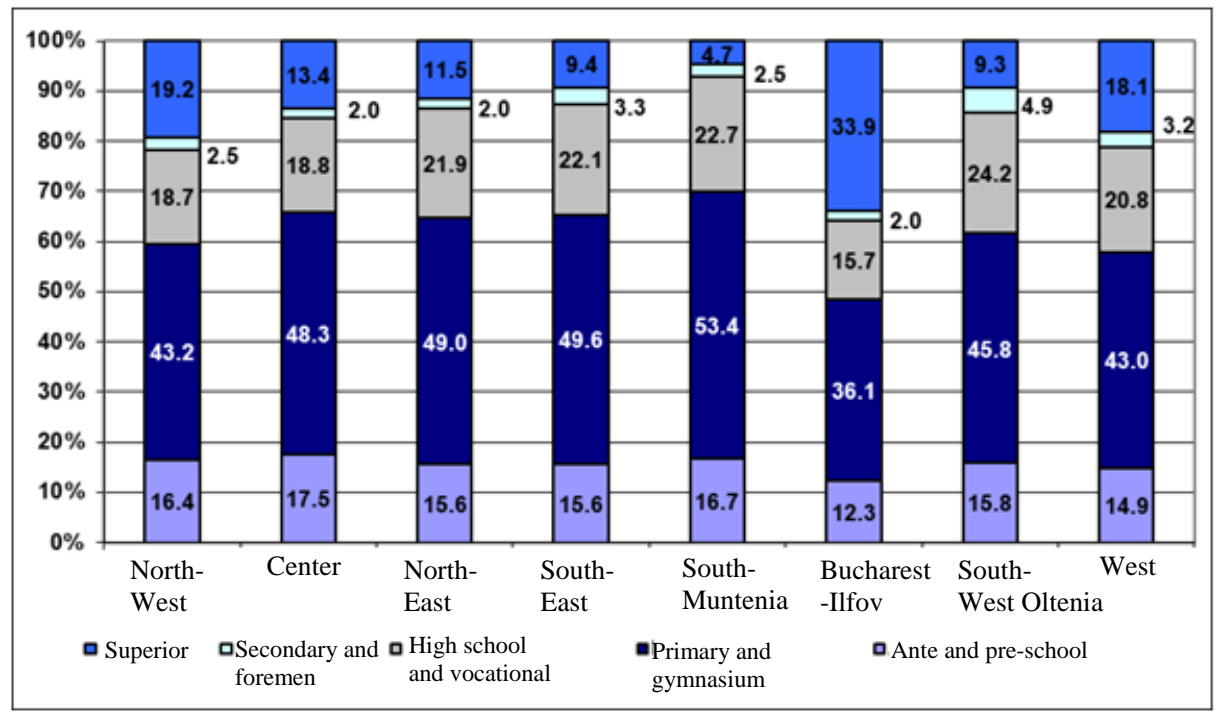

Figure 4. Distribution by regions of the school population by levels, in the school year 2019-2020

Source: INS, Comprehensive statistical research on education statistics

Regarding the distribution by rural and urban residence areas of the school population by education levels, it can be seen in Figure 5 their lower number in rural areas. It should be noted that the distribution of the school population in the territorial profile is made according to the geographical location of the school units and not according to the students' domicile.

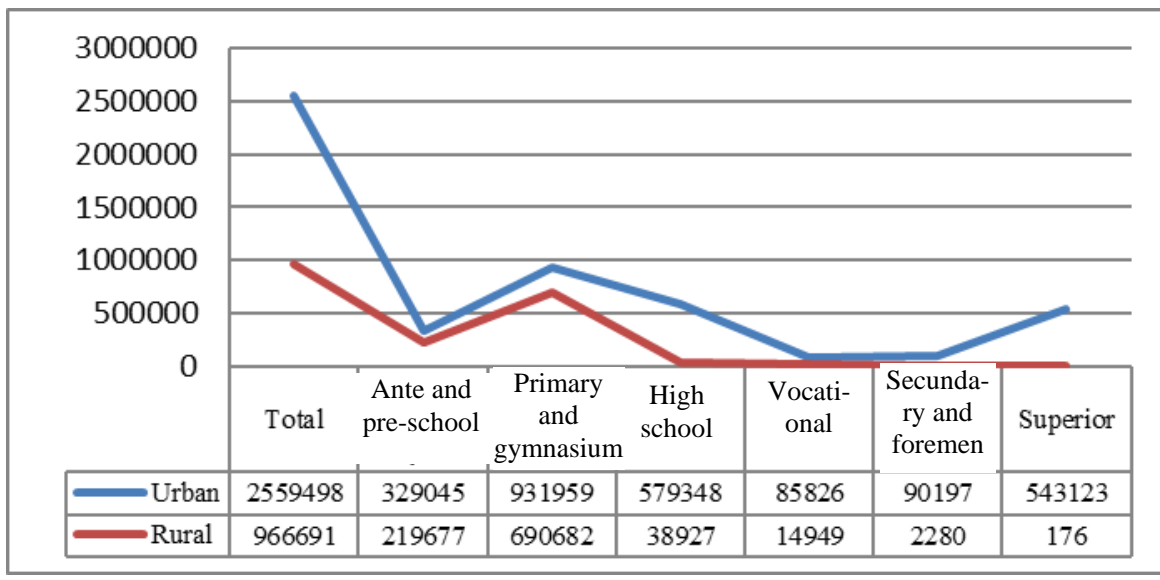

Figure 5. School population by educational levels in the school year 2019-2020

Source: Data processed by the author according to INS, Exhaustive statistical research on education statistics 


\subsection{Proper research}

The research took place at the "Tudor Vladimirescu" Technological High School from Tudor Vladimirescu commune, Galați county. The high school was founded in 1950, with an age of over 50 years in the area and has provided guidance and educational support over several generations of students (Andrei \& Zait, 2018, pp.39-56).

The study proposes the analysis of the use of the concept of exercise company in the valorization of the specific knowledge of entrepreneurship among high school students from rural areas. The research takes into account the specifics and characteristic features of the students in relation to the instructive and formative objectives pursued by the school curricula in force at the high school level.

The fair of exercise companies is a contest specific to this concept, but especially a favorable way to practice and apply the notions accumulated. Through trade fairs, students promote their products and services, but at the same time practice business transactions using negotiation tactics. Among the objectives of participating in the fairs we can list: motivating students, improving the specialized language, simulating a business environment as real as possible, empowering students and evaluating them.

The fairs of the exercise companies and the profile competitions were selected having in the official website of the training companies www.roct.ro and based on contacts with different teachers in the country, in order to participate in as many of them as possible. This allows the evaluation of the performance of the application of the exercise company concept for the development of entrepreneurial skills. As can be seen in Table 1 the two school years most awards were obtained by FE "Royal Guard" SRL in the sections spot, logo and slogan, power point presentation, promotional materials. We mention the fact that, due to the COVID-19 pandemic and the suspension of courses, most of the competitions expected in the second semester of the 20192020 school year took place online, lagging behind the initially approved schedule, and the results were submitted late.

Table 1. The results obtained from participating in trade fairs

\begin{tabular}{|c|c|c|c|c|c|}
\hline $\begin{array}{l}\text { Name Fair of } \\
\text { exercise } \\
\text { companies } \\
\text { 2018-2019 }\end{array}$ & $\begin{array}{l}\text { Contest } \\
\text { section }\end{array}$ & $\begin{array}{c}\text { Awards } \\
\text { FE "Royal } \\
\text { Guard" SRL }\end{array}$ & $\begin{array}{c}\text { Name Fair of } \\
\text { exercise } \\
\text { companies } \\
\text { 2019-2020 }\end{array}$ & $\begin{array}{l}\text { Contest } \\
\text { section }\end{array}$ & $\begin{array}{c}\text { Awards } \\
\text { FE } \\
\text { "Royal } \\
\text { Guard" } \\
\text { SRL }\end{array}$ \\
\hline $\begin{array}{c}\text { "Kretzulescu - } \\
\text { tradition and } \\
\text { contemporaneity", } \\
\text { December, 2018, } \\
\text { Bucharest }\end{array}$ & Negotiator & III & $\begin{array}{c}\text { "Kretzulescu - } \\
\text { tradition and } \\
\text { contemporaneity" } \\
\text { December, 2019, } \\
\text { Bucharest }\end{array}$ & $\begin{array}{l}\text { The best } \\
\text { PowerPoint } \\
\text { presentation } \\
\text { Slogan }\end{array}$ & Mention \\
\hline $\begin{array}{c}\text { Today's student, } \\
\text { tomorrow's } \\
\text { entrepreneur", } \\
\text { April 2019, } \\
\text { Focșani }\end{array}$ & $\begin{array}{c}\text { Seller } \\
\text { Stand staff } \\
\text { website }\end{array}$ & $\begin{array}{l}\text { III } \\
\text { Mention } \\
\text { Mention }\end{array}$ & $\begin{array}{l}\text { "Today's student, } \\
\text { tomorrow's } \\
\text { entrepreneur", May } \\
\text { 2020, Focşani }\end{array}$ & $\begin{array}{c}\text { Commercials } \\
\text { advertisement } \\
\text { Catalog }\end{array}$ & Mention \\
\hline $\begin{array}{l}\text { Regional Fair of } \\
\text { Exercise } \\
\text { Companies, April } \\
\text { 2019, Galați }\end{array}$ & $\begin{array}{l}\text { Negotiator } \\
\text { Catalog }\end{array}$ & Mention & $\begin{array}{l}\text { Regional Fair of } \\
\text { Exercise } \\
\text { Companies, April } \\
\text { 2020, Galați }\end{array}$ & Catalog & III \\
\hline
\end{tabular}




\begin{tabular}{|c|c|c|c|c|c|}
\hline $\begin{array}{l}\text { "From school to } \\
\text { life through the } \\
\text { exercise } \\
\text { company" April } \\
\text { 2019, Râmnicu } \\
\text { Vâlcea }\end{array}$ & $\begin{array}{l}\text { The best } \\
\text { presentation of } \\
\text { the multimedia } \\
\text { company - PPT }\end{array}$ & Mention & $\begin{array}{l}\text { "From school to } \\
\text { life through the } \\
\text { exercise company" } \\
\text { March 2020, } \\
\text { Râmnicu Vâlcea }\end{array}$ & $\begin{array}{l}\text { Professional } \\
\text { catalog }\end{array}$ & Mention \\
\hline $\begin{array}{c}\text { "Exercise } \\
\text { company, a career } \\
\text { launching pad", } \\
\text { April 2019, } \\
\text { Teregova }\end{array}$ & $\begin{array}{l}\text { The best } \\
\text { presentation of } \\
\text { the PPT } \\
\text { company }\end{array}$ & I & Postponed & - & - \\
\hline $\begin{array}{c}\text { "Young } \\
\text { entrepreneur in } \\
\text { the Virtual } \\
\text { Space", April } \\
\text { 2019, Bolintin } \\
\text { Vale }\end{array}$ & - & $\begin{array}{l}\text { Participation } \\
\text { diploma }\end{array}$ & $\begin{array}{l}\text { International Fair } \\
\text { of Exercise } \\
\text { Companies, May } \\
\text { 2020, Ploiești }\end{array}$ & $\begin{array}{c}\text { Materials } \\
\text { promotional }\end{array}$ & $\begin{array}{l}\text { Special } \\
\text { Prize }\end{array}$ \\
\hline $\begin{array}{l}\text { The competition } \\
\text { "From virtual to } \\
\text { real through } \\
\text { exercise } \\
\text { companies", April } \\
\text { 2019, Buzău }\end{array}$ & Web page & Mention & $\begin{array}{l}\text { The competition } \\
\text { "From virtual to } \\
\text { real through } \\
\text { exercise } \\
\text { companies", April } \\
\text { 2020, Buzau }\end{array}$ & $\begin{array}{l}\text { Commercials } \\
\text { advertisement }\end{array}$ & II \\
\hline $\begin{array}{l}\text { The online } \\
\text { competition } \\
\text { "Virtual today, } \\
\text { real tomorrow } \\
\text { through the } \\
\text { exercise } \\
\text { company", April } \\
\text { 2019, Alba Iulia }\end{array}$ & The best logo & II & $\begin{array}{l}\text { Fair of Simulated } \\
\text { Enterprises and FE } \\
\text { "I want to be an } \\
\text { entrepreneur" }\end{array}$ & $\begin{array}{l}\text { Materials } \\
\text { Advertising }\end{array}$ & III \\
\hline $\begin{array}{l}\text { "Steps to } \\
\text { success", May } \\
\text { 2019, Iasi }\end{array}$ & $\begin{array}{l}\text { Advertisement } \\
\text { Advertising } \\
\text { materials } \\
\text { Catalog }\end{array}$ & $\begin{array}{c}\text { I } \\
\text { II } \\
\text { Mention } \\
\end{array}$ & $\begin{array}{l}\text { "Steps to success", } \\
\text { March 2020, Iasi }\end{array}$ & $\begin{array}{c}\text { website } \\
\text { Commercials } \\
\text { advertisement }\end{array}$ & I \\
\hline $\begin{array}{c}\text { Virtual } \\
\text { competition } \\
\text { "Entrepreneurial } \\
\text { students, from } \\
\text { virtual to real", } \\
\text { June 2019, } \\
\text { Pașcani }\end{array}$ & & $\begin{array}{l}\text { Participation } \\
\text { diploma }\end{array}$ & $\begin{array}{c}\text { Virtual } \\
\text { competition } \\
\text { "Entrepreneurial } \\
\text { students, from } \\
\text { virtual to real", } \\
\text { June 2020, Pașcani }\end{array}$ & $\begin{array}{l}\text { The image of } \\
\text { the company } \\
\text { Presentation } \\
\text { Power-piont }\end{array}$ & $\begin{array}{l}\text { III } \\
\text { II }\end{array}$ \\
\hline
\end{tabular}

Source: data processed by the author

Figure 6 demonstrates the progress made in terms of results in the 2019-2020 school year compared to the 2018-2019 school year. It is noted that in all competitions in which the exercise company participated, a prize was won.

At the same time, there is a decrease in the number of entries and an increase in the number of 3rd and 1 st prize. 


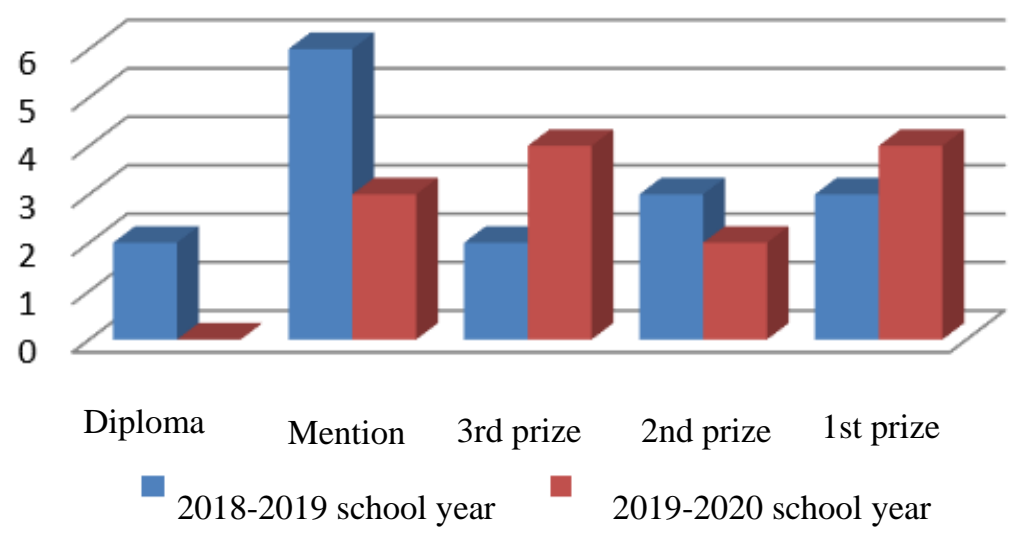

Figure 6. I he results obtained by $\mathrm{HE}$ "Koyal Guard" SRL

Source: data processed by the author

At the end of the courses, a questionnaire was applied to the students regarding their perception regarding the concept of the exercise company. All 21 students in the class answered the 10 questions. $57.1 \%$ of students consider setting up a company a moderate thing to do, and teamwork is considered by $66.7 \%$ of them a pleasant activity. Given that entrepreneurship involves sustained work, perseverance, leadership, $57.1 \%$ of students responded that they take on responsibilities and complete a task as shown in Figure 7; 42.9\% consider that they held the position of leader of a group. Most students, $77.1 \%$ want to continue their career in economics (trade, management, finance and banking).

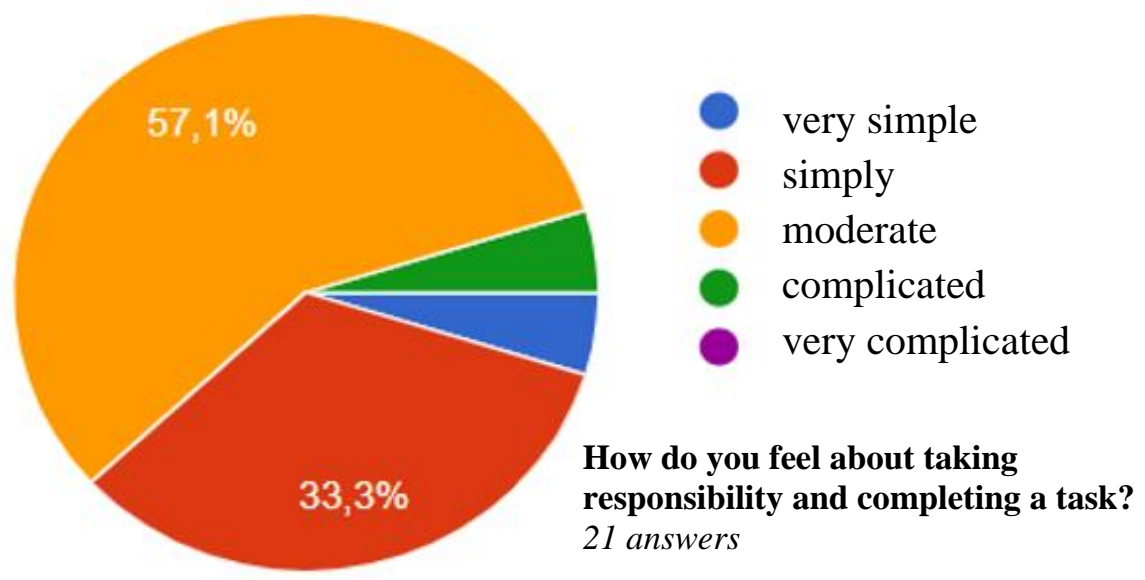

Figure 7. Students' perception of taking responsibility

Source: data processed by the author

Among the specialized modules, in the students' perception, the marketing, negotiation and contracting and company administration modules are the ones that allow the application of theoretical knowledge in practice.

$57.1 \%$ of students consider that the activities specific to the exercise company concept have contributed to increasing creativity in a practical way. We have employed a 5-point Likert scale ( 1 being considered the least, and 5 being considered the maximum).

Figure 8 highlights the fact that students support participation in trade fairs, and $66.7 \%$ of them appreciate this participation as very useful, choosing the maximum answer on a scale from 1 to 5 . 


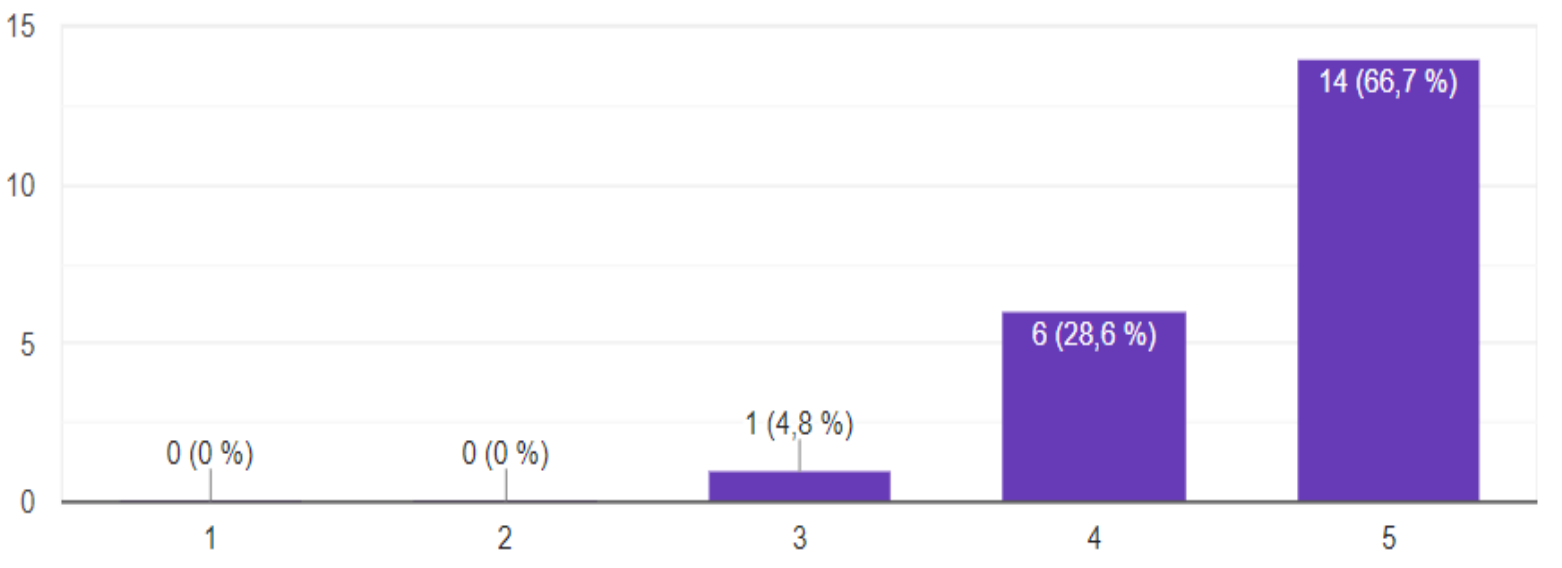

Figure 8. The usefulness of participating in trade fairs. The question:

Do you find it useful to participate in competitions and competitions of exercise companies?

21 Answers

Source: data processed by the author

When asked why they think that the experience within the exercise companies is useful, $52.4 \%$ of the respondents considered that they learn basic knowledge for building a career in the future and make the transition from the theoretical to the applied part of the notions using the concept exercise company. The variants learn basic knowledge for building a career in the future and gain flexibility in adapting to a job get $33.3 \%$ of the choices. $28 \%$ of students choose the answer are practicing situations of failure and success.

Figure 9 illustrates that $76.2 \%$ of students appreciated that the exercise company concept helps them to develop knowledge, skills and attitudes to be an entrepreneur.

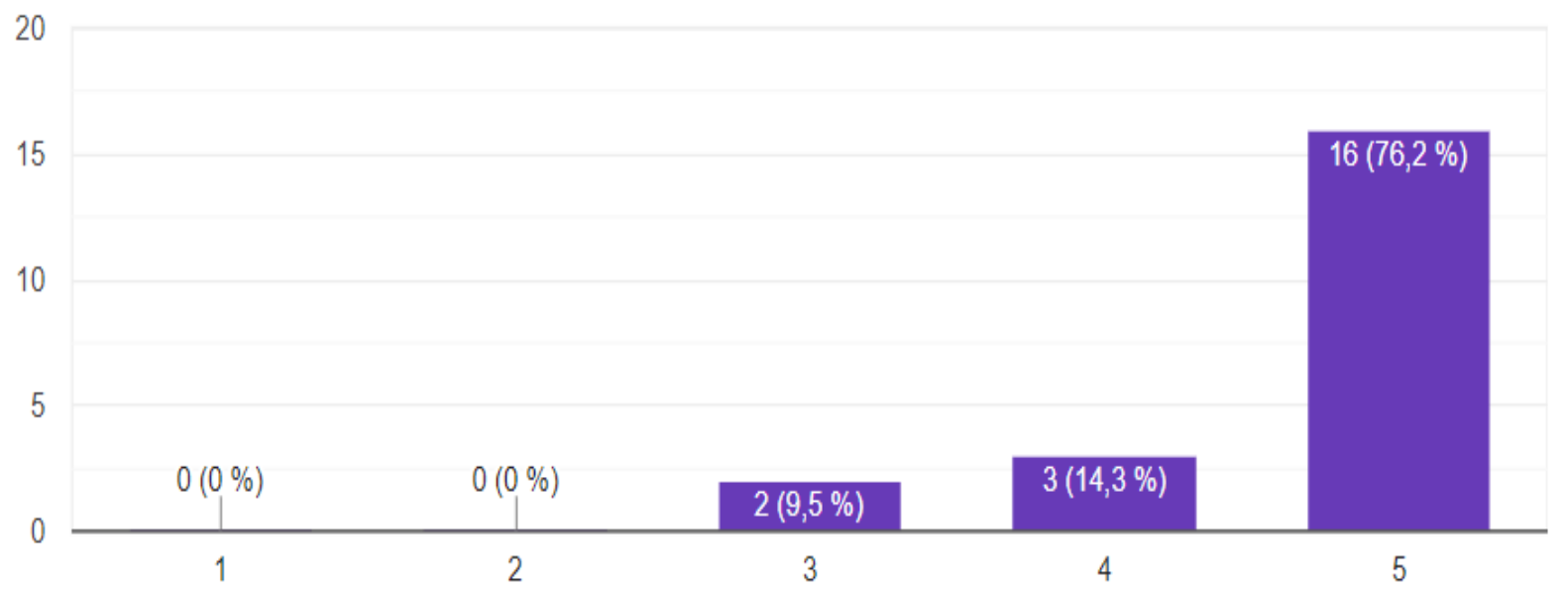

Figure 9. Students' perception regarding the development of entrepreneurial spirit through the exercise company.

The question: To what extent will the exercise company help you develop your personal knowledge, skills and abilities to be an entrepreneur? - 21 Answers Source: data processed by the author

The results obtained in the competitions and the answers in the questionnaire highlight the success of this concept among high school students for the development of entrepreneurial skills. 


\section{CONCLUSIONS}

Encouraging and developing entrepreneurship is a key objective of the European Union and the Member States. The potential of young people to start their own businesses is already revealed by putting into practice the knowledge, skills and attitudes they have learned in school. In this way, they can become innovators for the community in which they operate.

By creating new jobs and setting a personal example by opening new businesses, entrepreneurs implicitly contribute to the economic and social development of that community and raising the quality of life. This is all the more necessary in rural areas, which have a gap with the urban environment in terms of income, standard of living, opportunities for personal and professional development.

In line with the EU requirements regarding the introduction of entrepreneurial skills in the Romanian education system, Romania establishes a broader strategy with national funding allocated by the government and indirect European funds.

Entrepreneurial education introduced in the curriculum is cross-curricular, mandatory with teaching methods recommended by central authorities.

Romanian education, through its intrinsic mechanisms, has introduced a wide range of results of entrepreneurial learning at a single level, and practical entrepreneurial experiences are promoted.

For the technological branch of the high school, the introduction in the compulsory school curriculum of the concept of exercise company proved to be very auspicious.

By choosing, designing and using the most appropriate active-participatory methods by teachers, the concept of the exercise company for capitalizing on entrepreneurship enjoys a real success among high school students.

As it proved experimentally achieved over the two school years, by arousing motivation, practicality of method, attractiveness of entrepreneurial concepts, students who were part of the exercise company "Royal Guard" SRL achieved performance as a result of participating in competitions.

The very fact that they worked in a team, dedicated extra time, often stayed for the school program, learned new digital applications, denotes the success of the firm concept of exercise and implicitly the development of entrepreneurship, even among students' rural high school.

Participation in trade fairs, in addition to developing the practical part, was a way for students to make friends with students from other high schools and other counties in the country, exchanged examples of good practice, but especially took place. an increase in self-esteem.

They realized that they are no better than other renowned high school students in big cities, that their ideas and their applicability is recognized by other teachers and business representatives.

The questionnaire on assessing the level of student satisfaction in the exercise company highlighted the fact that after two years of applying this concept, students work better in a team and take on responsibilities more easily; gets more involved in projects over a longer period of time and also accepts leadership positions; through the exercise company you learn basic knowledge for building a career in the future and for the applicability of theoretical notions.

But most importantly, most believe that the exercise company helps them a lot to develop as entrepreneurs. In this sense, we intend to continue the research in the following school years.

We believe that boosting entrepreneurship, especially in rural areas, where living conditions are more precarious than in urban areas, is a real premise for sustainable rural development. 


\section{REFERENCES}

Andrei, A., G., Zait, A. (2018). The Sharing Economy in Post - communist Societies: Insights from Romania. In: E.-M. Vătămănescu and F.M. Pînzaru, eds. Knowledge management in the sharing economy: cross-sectoral insights into the future of competitive advantage, Knowledge Management and Organizational Learning. Cham: Springer International Publishing. Chap. 3, pp.39-56.

Bosma, N. \& Kelley, D. (2019). Global Entrepreneurship Monitor, Grafica Andes, Chile, available at https://www.gemconsortium.org/report/gem-2018-2019-global-report, retrieved July 29, 2020.

Cantillon, E. (2001). Electoral Rules and the Emergence of New Issue Dimensions, Cowles Foundation Discussion Papers 1291, Cowles Foundation for Research in Economics, Yale University.

Ceocea, C. (2014). Teoria şi practica deciziei manageriale. Editura Economică, Bucureşti.

Ceocea, C., Bibire, L. \& Ghenadi, A., S. (2014). Risk management planning within romanian companies. Journal of Engineering Studies and Research, 20 (3), pp. 13-23, available at https://www.researchgate.net/publication/328616283_RISK_MANAGEMENT_PLANNING_ WITHIN_ROMANIAN_COMPANIES, retrieved July 5, 2020.

Comisia Europeană (2012). Comunicarea Comisiei către Parlamentul European, Consiliu, Comitetul Economic și Social European și Comitetul Regiunilor, Stasbourg, pp. 4, available at https://eur-lex.europa.eu/legal-content/RO/TXT/PDF/?uri=CELEX:52012DC0669\&from=ro, retrieved July 10, 2020.

Comisia Europeană/EACEA/Eurydice (2016). Educația antreprenorială în şcolile din Europa. Raport Eurydice, Luxemburg: Oficiul pentru publicații al Uniunii Europene, pp. 13, 50 - 61, 65-68, 73, available at https://op.europa.eu/ro/publication-detail/-/publication/74a7d356-dc5311e5-8fea-01aa75ed71a1, retrieved July 10, 2020.

Drucker, P. (1993). Inovația și sistemul antreprenorial. București, Editura Teora.

Eroğlu, O. \& Piçac, M. (2011). Entrepreneurship, National Culture and Turkey, International Journal of Business and Social Science, 2(16), pp. 146-151.

European Commission, (2019). Agriculture, forestry and fishery statistics 2019 edition, Luxembourg: Publications Office of the European Union, PDF ISBN 978-92-76-13193-9 ISSN 2363-2488 doi:10.2785/798761 KS-FK-19-001-EN-N, pp. 190-191, online at https://ec.europa.eu/eurostat/documents/3217494/10317767/KS-FK-19-001-ENN.pdf/742d3fd2-961e-68c1-47d0-11cf30b11489, retrieved June 15, 2020.

Europen-Pen International, Practice enterprise network, available at https://www.penworldwide.org/about-us/concept/, retrieved July 20, 2020.

Kerr, S., P., Kerr, W. \& Xu, T. (2017). Personality traits of Entrepreneurs: a review of recent literature, Harvard Business School, available at https://www.hbs.edu/faculty/ Publication\%20Files/18-047_b0074a64-5428-479b-8c83-16f2a0e97eb6.pdf, retrieved July 20, 2020.

Schumpeter, J., A. (1949). Economic theory and entrepreneurial history, in Wohl, $R$. R. (ed.), Change and the entrepreneur: postulates and the patterns for entrepreneurial history, Research Center in Entrepreneurial History, Cambridge, Massachusetts: Harvard University Press.

Toderiţă, A. \& Tom, B. (2019). Politici publice pentru viitoarea generație de fermieri a României, în cartea Caiet documentar 4 - Agricultura. Concepte și instrumente operaționale, coordonatori Stoian, M și Aniței, M., Editura Club România, București, 2019, pp. 1129-1138, available at http://www.mentoringproject.ro/wp-content/uploads/2019/04/CD4\%20\%20Agricultura.pdf, retrieved July 15, 2020. 
Țîțu, A., M., Pop, A., B. \& Ceocea, C. (2019). Risk Assessment of Physical Security within a Technologized Knowledge Based Organization, in MATEC Web of Conferences 299(7):04005, January 2019, pp.1-6 available at https://www.researchgate.net/publication/337676251_ Risk_Assessment_of_Physical_Security_within_a_Technologized_Knowledge_Based_Organiz ation/link/5de506654585159aa45a5e68/download, retrieved July 5, 2020.

Smart, D. \& Conant, J., S. (1994). Entrepreneurial orientation, distinctive marketing competencies and organizational performance. Journal of Apllied Business Research, 10 (3), pp. 1-28.

Timmons, J., A. (1989). The antrepreneurial mind, Andover, Brick House Publishing.

Wennekers, S. \& Thurik, R. (1999). Linking Entrepreneurship and Economic Growth, Small Business Economics, 13, pp. 27-55.

http://www.roct.ro/ 